\section{Flesh of my Flesh: the Ethics of Cloning Humans}

\author{
Edited by Gregory E Pence, New \\ York, Rowman and Littlefield, 1998, \\ 154 pages, $£ 8.95$.
}

This book assembles a collection of previously published articles on cloning by a variety of authors including biologists, ethicists, legal professors and theologians. The articles come from various sources such as The Atlantic Monthly, The New York Times, The New Republic, Nature, and The New York Times Review of Books. The earliest one, was published in 1971, well before the sheep Dolly was cloned and gives some historical background to the subject. The rest were all published in 1997. The authors include James D Watson, R C Lewontin, Philip Kitcher, George Annis, Axel Kahn and Stephen Jay Gould. It is certainly useful to bring together such a diversity of views although a certain note of urgency is struck by some of the authors - as though an invasion of the USA by an army of cloned humans were imminent! In some ways the most useful chapter is an extract from the National Bioethics and Advisory Commission that was convened by President Clinton to pronounce on the ethics of human cloning. The commission's reasonings and arguments for their announcement of a moratorium on the use of federal funding for research into human cloning and for their calling on Congress to pass a law making it a federal crime to create a child by somatic cell nuclear transfer, are given. The rest of the authors in this volume either align themselves for or against human clon- ing; and the opponents to cloning appear to outweigh considerably the proponents. The reasons given for opposition to cloning are mainly: issues to do with the safety of the procedure; inability to obtain informed consent; possible impaired identity and individuality of the cloned child; distortion of family relationships and values; arousal of feelings of repugnance and dehumanisation by onlookers; treating children as objects and products of a bio-technology, and finally violation of scripture (Christian, Judaic, Islamic etc).

Among the proponents for human cloning the main issues appear to be: maintaining reproductive and family freedoms; freedom of choices for individuals to procreate; rights to genetic privacy; preservation of scientific freedom to undertake new procedures, and a possible new method to combat sterility. The last chapter deals with cloning as a means of perpetuating the DNA of minority groups whose sexual orientation precludes the usual forms of procreation. There is a great deal of repetition as six of the thirteen chapters go over the same ground, ie the experiments leading up to the cloned sheep Dolly and most of the thirteen chapters deal with the above mentioned pros and cons, putting different values and weights on each of the objections or approvals for the procedure. All the authors are from the USA, despite the fact that the somatic cell nuclear transfer techniques originated in the United Kingdom, and most of the authors feel an urgency that something should be done about human cloning. It would have been informative to have had some European views. If the technology is possible it eventually will be used although this is probably a long way from prac- tice as yet. However, the statemerfes and opinions in the book do need to discussed in an open forum: a consef sus needs to be reached with a view forming eventually some type of regulatory framework to monitor the progress of cloning experiments. Opre author suggests a new federal agençy should be set up, such as a commrssion on human experimentatio $\vec{B}$. which would have stautory powers to license and to regulate the complex issues that will undoubtedly arise. TR current books and articles on huma cloning appear to be outnumbering the experiments done on human (or even animal) cloning but this volurfie is certainly another way into the puto lic debate. I found it quite a useful compendium.

DAVID J GALTO $\overrightarrow{\mathrm{N}}$

Department of Metabolism and Genethe, St Bartholomew's Hospit], London EC1A 7

\section{Books: information and orders}

If you wish to order or require further information regarding the titles ro viewed here, please write or telephone the BMJ Bookshop, PO Box 293 London WC1H 9JR. Tel: 017138 6244; fax: 0171383 6455; Interne www.bmjbookshop.com; emait. orders@bmjbookshop.com. Europe率 customers should add 15 per cent for postage and packing, other oversegs customers should add $30 \%$. Paymeat can be made by cheque in sterling drawn on a UK bank or by credit ca (Mastercard,Visa, or American Express, stating card number, expiry date and full name. (The price and availabality are occasionally subject revision by the publishers.) 